\title{
Reflection of Intercultural Concepts in the Work "Baburnama"
}

\author{
Siuita Abdykadyrova ${ }^{1}$, Sabyrkul Kalygulova ${ }^{2}$, Karamat Belekova ${ }^{3}$, Rakhat Sagyndykova ${ }^{3}$, \\ Gulmira Zheenbekova ${ }^{3}$, Altynai Ismailova ${ }^{3}$, Zhypargul Osmonbaeva ${ }^{3}$, Samara Pazilova1, \\ Makhlie Nazarova ${ }^{2}$, Zhypargul Abdullaeva ${ }^{*}$ (i)
}

\footnotetext{
${ }^{1}$ Department of Romance and Germanic Philology, Osh State University, Osh, Kyrgyzstan

${ }^{2}$ Department of Phonetics and English Grammar, Osh State University, Osh, Kyrgyzstan

${ }^{3}$ Department of English Teaching Methods, Osh State University, Osh, Kyrgyzstan

${ }^{4}$ Science and Research Department, Osh State University, Osh, Kyrgyzstan

Email: ${ }^{*}$ jypar.science@oshsu.kg
}

How to cite this paper: Abdykadyrova, S. Kalygulova, S., Belekova, K., Sagyndykova, R., Zheenbekova, G., Ismailova, A., Osmonbaeva, Z., Pazilova, S., Nazarova, M., \& Abdullaeva, Z. (2021). Reflection of Intercultural Concepts in the Work "Baburnama". Open Journal of Modern Linguistics, 11, 140-148.

https://doi.org/10.4236/ojml.2021.112012

Received: March 1, 2021

Accepted: March 27, 2021

Published: March 30, 2021

Copyright $\odot 2021$ by author(s) and Scientific Research Publishing Inc. This work is licensed under the Creative Commons Attribution International License (CC BY 4.0).

http://creativecommons.org/licenses/by/4.0/

\begin{abstract}
The main purpose of this article is to define intercultural concepts in one of the most ancient monuments of Turkic culture work "Baburnama", written by Zakhiriddin Muhammad Babur. This article describes the understanding of the term "intercultural concept" and its main features with characteristics. Intercultural concepts usually represented by words in the national and cultural semantics, occupy an actual place in the linguistic picture of the world, contributing to the study of its ethical and mental identity in the minds of native speakers. The research objects are intercultural concepts in the text "Baburnama" as the most important components of Central Asian peoples' national culture. We clarified the artistic and intercultural concepts based on the research works of domestic and foreign linguists' opinions. The relevance of addressing intercultural concepts study in the text "Baburnama" is due to insufficient research of intercultural concepts, which are reflecting various important social and spiritual phenomena in the life of Central Asian people for a long time.
\end{abstract}

\section{Keywords}

Concept, Text, Intercultural Concept, Culture, Literature, Ethnos, Worldview, Baburnama, Linguistic Picture of the World

\section{Introduction}

The study of intercultural concepts provides opportunities for the study of individual linguistic features that characterize a particular ethnic group. Under- 
standing of this concept as semantic structure is unfolding in the range from genotype to stereotype (Popova \& Sternin, 2002). Intercultural concepts unite representatives of not one ethnos, but a complete multilingual community linked by a common history, territory, economic, political, religious, and other relations. Analysis of the linguistic picture of the world (Vulchanova et al., 2019) resulted from the language perception relationship, and the visual world paradigm demonstrating relationships between people linguistic and perceptual information. At the same time, an important stage in comprehending the deep laws of the general linguistic picture of the world, the linguistic ideas of a person about the world, as well as his spiritual world and the spiritual culture of society can be reflected from interdisciplinary introduction to the study of language, by drawing not only on the diverse fields of linguistics, such as structural, linguist anthropology, historical, sociolinguistics, biology, genetics and sociology (Andresen \& Carter, 2016).

The work is of great theoretical importance, since the study of ethnic consciousness through the prism of intercultural concepts expressed in literary texts is important in cultural linguistics.

Babur (Figure 1) is also known as a founder of the Mughal Empire by Sunni Muslim Chaghtai conquest, thrived for almost two centuries; his ideology provides establishment of harmony between people, as well as the education introduction in all population segments (Fraser, 2018; Yorieva, 2020). "Baburnama" is Babur's personal diary series, which he kept throughout his life, which is not only a description of his personal life, but also a valuable source for the study of history, culture, everyday life of people, flora and fauna of regions visited by Babur (Advantour, 2021).

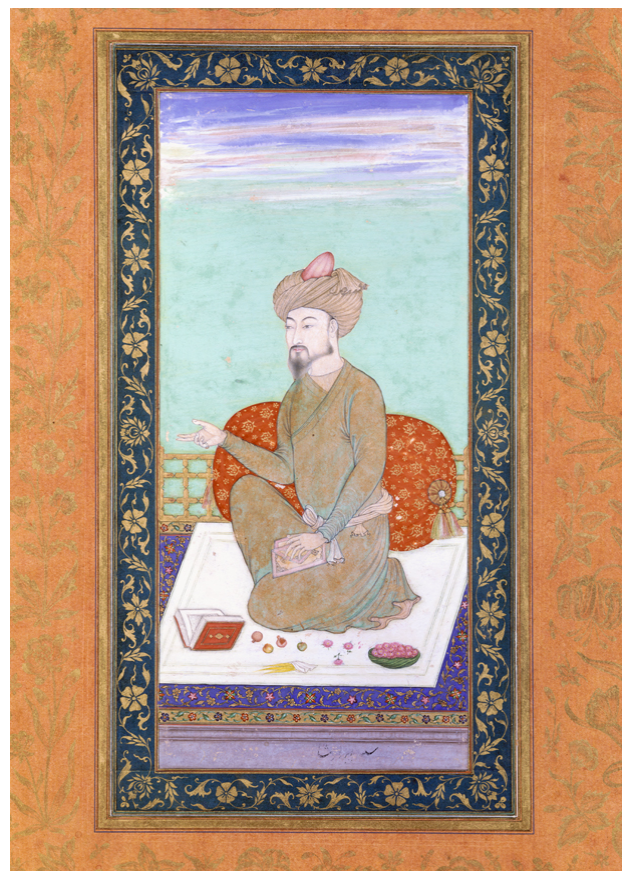

Figure 1. Babur portrait, XVII century. 
Each nation has its own linguistic picture of the world, which is based on universal and nationally specific values. In addition, the people language reflects a certain way of perceiving and organizing the world. Expressed meanings were added to a certain system of views, which is mandatory for all native speakers. The pictures of the world of different nations are somewhat similar to each other but different in other way.

\section{Research Theoretical Foundations}

The main research method in our research was focused the textual analysis and descriptive method of the artistic work "Baburnama". The methodological basis for this literary monument formed by the approach to the literary text as a work on speech and the use of a set of techniques for studying the intra-lingual and extra-linguistic specifics of the medieval text. The main methods of work of this study were the descriptive, historical and etymological methods and textological analysis of the literary work "Baburnama". The main purpose in our research is the description and analysis of intercultural concepts in the work "Baburnama", and identification of their specific features based on other aspects given in this work.

To substantiate the specificity of intercultural concepts use in the work "Baburnama", firstly it is necessary to clarify the concept of "intercultural concept" (Singh, 2020). Although the concept in science has not yet received a complete and precise definition, many varieties of the concept have appeared in linguistics. It also can be defined as a cultural concept, scientific, artistic, intercultural, linguocultural, etc. In our case, we used the intercultural concept, the signs, and properties of which we want to present in this work.

The term concept was defined by V.I. Karasik as following: concepts are mental formations, which are stored in the memory of a person, meaningful, conscious typified fragments of experience, "a quantum of experienced knowledge" (Karasik, 2004). According to S.G. Vorkachevs definition, the concept is "a unit of collective knowledge ... having a linguistic expression and marked by ethnocultural specifics" (Vorkachev, 2001). The intercultural concept, as its name is common to the linguistic picture of the world people from the certain area, in this study, from the Central Asian area.

The research results by G.A. Madmarova turned out to be very useful for us in the monograph "Regional Intercultural Concepts in Literary Text". Considering intercultural concepts in the text of a work of art, G. Madmarova presented her study results about intercultural concepts and regional words from the text in works of S.P. Borodin's tetralogy "Stars over Samarkand" (about events from XV to XVI centuries), and A.von Beck's novel-trilogy "The Huns" (about the history of the Huns in the III to IV centuries a.d.). G.A. Madmarova considered lexical units, both diachronic and synchronicity in terms, because of centuries-old Iranian, Arab, Mongolian, and mainly Turkic peoples throughout the Eurasian space (Madmarova, 2018). She introduced the term intercultural concept, which 
unites conceptual pictures of the world belonging to Central Asian people. Thus, it can be stated that, intercultural concept is a lump of meaning that is verbalized in words, phrases, phraseological expressions, paremias, and etc., although most of their meanings and connotations cannot be adequately represented by words, and refer to various versions in the linguistic pictures of the people from a certain region.

It seems that especially important components of intercultural concepts have a culturological essence, and a certain repetition with recognition, as each person has an innate set of emotions that recognized universally (Chronaki et al., 2018). They can characterize a certain mentality, cultural era, worldview of people from a particular region, and therefore can serve as a characteristic of the national picture of the world.

Consequently, concerning the tasks of this work, we will consider cross-cultural concepts that:

1) are present in the mental consciousness of several Central Asian people;

2) reflect the peculiarities of the national specifics of the Turkic people;

3) convey concepts and phenomena that are particularly important for these cultures;

4) Intercultural concept exponents characterized by a fairly high degree of frequency in the languages of a certain region;

The inhabitants of a certain region, connected by a common historical past, cultural, economic, and political ties are also characterized by some common words in their language. The cross-cultural concept, as its name implies, is common to the linguistic picture of the world of people in a certain area. In our case, we consider Central Asian people.

\section{Analysis of Some Intercultural Concept Nominees in "Baburnama"}

Each text has a distinct cultural background behind the words. Civilization, culture, social status in general has an influence on the text. The key constructs for the study of the linguistic picture of the world are concepts. This is a semantic unit that is reflected in the language, and, consequently, in the text.

The book "Baburnameh" has entered the treasury of world culture as a magnificent example of prose and a valuable historical source. The ruler-poet Babur left a great legacy, both poetic and territorial; it is quite unusual that Babur wrote his notes himself, without the help of historians and scribes. This once again shows his education, sharp analytical mind, and writing talent.

Cross-cultural concepts play a significant role in the text Baburnama: they characterize the most important life aspects and Central Asian people everyday life in those times; they convey the mental characteristics of these ethnic groups, their worldviews, and outlooks. In Babur's narrative work, additional basic concepts are the cross-cultural concepts conveying the national specifics of the people under consideration, and results of their spiritual activities. As it is 
known, the migration of Turkic speaking and Iranian speaking people took place in Central Asian region. Also, the frequent presence of Semitic, Mongol-speaking people and tribes observed. Therefore, the mixing of languages in this region was particularly intense. Babur wrote about the language situation in Kabul (this city was not part of Afghanistan) at that time: "In the valleys and plains there are aimaks, Turks and Arabs; in the city and some villages there are Sarts (Tajiks). In other villages and regions live passai, piracy, Tajiks, bereki, and Afghan people. In the mountains of Ghazni are living hazare and nikuderi tribes. Among the hezari and nikuderi tribes, some of them are speaking in Mongolian language... In the Kabul region, ten or twelve languages are spoken: Arabic, Persian, Turkic, Mongolian, Indian, Afghan, Peshshai, Perachi, Gebri, Bereki, Lamgani. In no other region, as far as is known, do so many different tribes live, speaking different languages" (Salie, 1948).

We can see that the linguistic situation of that time implied multilingualism. Babur himself wrote in both Turkic and Farsi languages. In this regard, at present, the languages of the Central Asia people have a layer of common words, the exact etymology of which is not always possible to determine without special research. The linguistic picture of the world of these people is also reflected in the representation of concepts, in various versions available in the language of each people.

Representatives of cross-cultural concepts in Baburnama refer to the most diverse aspects of described people life: military terms, household terms related to clothing, food, and drink; tribal, toponymic, and onomastic names, titulature, and so on.

Next, let us pay an attention to some nominees in intercultural concepts in "Baburnama" and try to consider their meanings. Babur has many interesting words that are often not explained by him, but their meaning is clear enough to a reader who is versed in the Turkic languages.

For example, the word tagay is used as a part of the name of the bek, in fact, the term of kinship taga, very common in the Turkic languages: "Another one was Ali Dust Tagay, from the beks of the fog Sagarichi, a relative of my mother's mother, Isan Daulat bikim. I showed him more favors than (those that he enjoyed) at the time of Omar Sheikh Mirza" (Salie, 1948).

In the meaning of "maternal relatives" in the Turkic languages, there are the words nagashi, taga, dayy/tayy. L.A. Pokrovskaya considers the word uncle in the Kazakh language as a variant of the word nagaly in the Mongolian language, i.e., as a borrowed word (Pokrovskaya, 1968).

The word taga is found in Kyrgyz, Uzbek and Uyghur languages. K. Yudakhin explains this term in the Kyrgyz language as "parent from the mother's side" (uncle) (Yudakhin, 1965). The Kyrgyz Russian dictionary notes that the word taga is characteristic of the southern Tien Shan dialect. Utegenova G.Zh. writes that "the word Taga arose on the basis of the penetration of Thai and the senior words. This is how the word tayake was made in the Kyrgyz language (meaning 
'nagashy papa'). In other Turkic languages the words tai, dain give the meaning 'nagashi'. In the Mongolian language, the word taabai is used in the meaning of nagashi. One of these Turkic languages, including the languages of Altai (Taai), Tuva (Daai), Yakut (Taai), has a word root with a stretching vowel" (Utegenova et al., 2019). We don't quite understand what it means senior words, we assume that this means penetration from ancient sources.

In the above example from Babur's text, the term biki, bikim was noted. It serves as a prefix to the name of women of a noble family. Most likely, it comes from the title bek/ bey/biy which means noble, rich. Among the Turkic speaking people, the leaders of individual regiments or squads who were in the service of the khan, the ruler, were called as beks. They enjoyed great privileges and constituted the highest military nobility.

In the former Turkish Empire, the Bey ruled over the area. In the Central Asian countries, the beks were the highest nobility. The khans appointed them as governors of certain regions. Initially, the word bek, appended to the name, served as a special distinctive sign (title).

In Babur's text, we see the following lines: "My father Omar Sheikh Mirza showed him (Tulun Khoja) attention and all the time showed him a favor. I also showed concern for him and made him a Bek" (Salie, 1948). "There was no support and help from the neighboring and neighboring sovereigns and beks" (Salie, 1948). We see that at the time of Babur, bek was a title that could be earned. Later, as you know, this title became hereditary, and after that, it could be used as a form of polite address to a person, an indicator of the degree of respect.

The prefix bikim/begim or biki was used as a female title in the medieval Turkic-Mongol khanates: the daughter of Ulukbek Guragan Rabiya Sultan-begim. "The eldest of all daughters was Khanzade Bikim; she was born from the same mother with me and was five years older than me" (Salie, 1948). "Another son was Sultan Ali Mirza; his mother was Zukhra Biki Agha” (Salie, 1948). The synonym for the title bikim was the word khanum: "Another son was Sultan Vais Mirza; his mother was Sultan Nigar khanum, the daughter of Yunus Khan, the younger sister of my mother" (Salie, 1948). "In nine hundred and ten, Baki Chaganiani came to my service on the bank of the Amu River; both of these Bikim (Ak Bikim and Ai Bikim) together with their mothers were in Termez" (Salie, 1948). In this case, Bikim means "princess".

Babur mostly spelled Biki with a capital letter as part of the name, and as a title, Bikim is written with a small letter after the name: Khadicha Bikim, Khanzade Bikim, Appak Bikim, Zuhra Biki Agha, etc. Like the title bek, the bikim could not be a hereditary title, it could be earned: "There was also Khadicha-bikim, the concubine of Sultan-Abu-Said Mirza ... After the death of Sultan-Abu-Said Mirza in Iraq, she arrived in Herat; in Herat, Sultan-Hussein took her and fell in love. From the degree of a concubine, she rose to the degree of $b i$ kim and later became very powerful" (Salie, 1948).

Thus, a bikim could mean not only a princess but also an honorary degree 
that could be acquired.

The concept of murid/miurid is of a certain interest. It is used in fiction not so often, but in Babur works, it is quite frequent. When talking about his father, he calls him murid. "He (Omar Sheikh Mirza) was a murid of the venerable Khoja Ubayd Allah and often received a conversation with him. Venerable Khoja even called him a son" (Salie, 1948). Murid (from Arabic language) In Sufism is a disciple is at the first stage of initiation and spiritual self-improvement. In wider usage, it can be denoted as a Sufi in general and even just an ordinary Muslim. Perhaps this is because the duties of a murid were almost no different from those of any Muslim: to perform all five prayers on time, in a clean place, to be cleanly dressed; behave as if Allah is constantly watching him; respect your sheikh; do not question his words, do not doubt the teaching, etc.

Given nominative is well known in Russian and is given in many dictionaries of the Russian language in the meanings: 1) Muslim novice, warrior, brought up in the spirit of absolute subordination to his leader, 2) Pupil of a dervish sheikh; 3) Muslim novice, 4) Novice, 5) A person who wants to devote himself to Islam and master the basics of mystical sufism teaching, 6) Follower of Sufism, disciple of a dervishe sheikh. We find the same approximately meanings in the dictionaries of Ushakov D.N., in the new explanatory dictionary of the Russian language a Efremova T.F., in the Great Soviet Encyclopedia, and others. In the "Dictionary of Synonyms" V.N. Trishin (2013) also gives the meaning of "fanatic".

In Babur's work, term murid defined as a follower of a sufi teacher. Being a murid in those days was honorable, especially for such a famous person as Khoja Ubayd Allah. Babur gives the meaning of "disciple" as different from murid: "There were also Mullah Masud Shirvani and Mullah Abd-al-Ghafeu from Lara. The latter was both a murid and a disciple of Maulan Abd-ar-Rahman Jami" (Salie, 1948). Currently, this nominee is not very common in the languages of the Central Asian people. In the Caucasus, even in the recent past, it functioned in the meaning of "a follower of the mystical Muslim sect founded by Shamil in the Caucasus" (Prozorov, 1991).

\section{Conclusion}

In summary, analysis of some intercultural concepts in the text "Baburnama" allows us to draw the following conclusions:

1) Babur uses intercultural concepts as a means of conveying primordial Turkic realities, specifically national concepts and phenomena of people from the Central Asian region.

2) The fact that Türks had special names for expressing the degrees of kinship indicates strong feelings.

3) Intercultural concepts indicate that Central Asian people have a common past, a similar mentality and worldview, which was reflected in a certain way in the language. This can be clearly seen in the Babur works.

Because of considering this issue, we can say that intercultural concepts in 
Babur's works vividly recreate historical, cultural, and linguistic pictures of the world of the Central Asian people living in the middle ages, and fragments of reality presented in the work "Baburnama". Through this works, we can see the spiritual culture of an author himself and his period, intercultural concepts used in the Babur's work showed us multilingual community connected by a common history, territory, economics, politics, religion and other issues. At the same time, it should be emphasized that the lexical units objectifying cross-cultural concepts in the work "Baburnameh" were formed under the direct influence of socio-historical, economic, cultural, religious and other factors, and represented a complex system that emerged in the process of centuries old historical development. Most of these units are continuing to be used in modern Turkic and Mongolian languages, often with minor changes.

Scientific and practical significance of the work related to proposed research that is providing theoretical and practical significance in the study of the languages, written monuments of Turkic culture, and the linguistic picture of Central Asian people world. Study of certain concepts in the artistic work "Baburnama" enriches the individual consciousness of the reader, expanding the boundaries of his ideas about the most important universal and national values.

\section{Conflicts of Interest}

The authors declare no conflicts of interest regarding the publication of this paper.

\section{References}

Advantour (2021). Zahiriddin Muhammad Babur: Military Leader, Politician, Poet. https://www.advantour.com/rus/uzbekistan/culture/literature/babur.htm

Andresen, J. T., \& Carter, P. M. (2016). Languages in the World: How History, Culture, and Politics Shape Language (400 p.). Hoboken, NJ: Wiley-Blackwell.

Chronaki, G., Wigelsworth, M., Pell, M. D., \& Kotz, S. A. (2018). The Development of Cross-Cultural Recognition of Vocal Emotion during Childhood and Adolescence. Scientific Reports, 8, Article No. 8659. https://doi.org/10.1038/s41598-018-26889-1

Fraser, T. G. (2018). Mughal Diplomacy. In Encyclopedia of Diplomacy (2168 p). Hoboken, NJ: Wiley.

Karasik, V. I. (2004). Linguistic Circle: Personality, Concepts, Discourse (p. 435). Moscow: GNOSIS.

Madmarova, G. A. (2018). Regional Intercultural Concepts in Literary Text. Bishkek.

Pokrovskaya, L. A. (1968). Kinship Terms in the Turkic Languages. In Historical Development of Turkic Languages Vocabulary (468 p). Article Collection, Moscow: SSSR Academy of Sciences.

Popova, Z. D., \& Sternin, I. A. (2002). Concepts and Intercultural Communication. Voronezh State University Bulletin. Series: Linguistics and Intercultural Communication, $1,117-121$.

Prozorov, S. M. (1991). Islam. Encyclopedic Dictionary(315 p.). Moscow: Science GRVL. Salie, M. (1948). Babur-Name (270 p.). Tashkent: Gosizdat UzSSR.

Singh, P. (2020). Speaking Truth to Power: Exploring Guru Nanak’s Bābar-vāṇī in Light 
of the Baburnama. Religions, 11, 328. https://doi.org/10.3390/rel11070328

Utegenova, G. Zh., Shoibekova, A. A., \& Bazarbekova, N. Sh. (2019). Study of Related Names in Turkic Languages. In Languages of the Peoples of Foreign Countries of Europe, Asia, Africa/Philological Aspect No. 10 (54) (p. 163). Nizhniy Novgorod: Open Knowledge.

Vorkachev, S. G. (2001). Linguoculturology, Linguistic Personality, Concept: The Formation of an Anthropocentric Paradigm in Linguistics. Philological Sciences, 1, 64-72.

Vulchanova, M., Vulchanov, V., Fritz, I., \& Milburn, E. A. (2019). Language and Perception: Introduction to the Special Issue "Speakers and Listeners in the Visual World". Journal of Cultural Cognitive Science, 3, 103-112. https://doi.org/10.1007/s41809-019-00047-z

Yorieva, M. O. (2020). Zakhiriddin Babur Is a Patriot, Politician and Poet. Science and Education Issues, 7, 44-48.

Yudakhin, K. K. (1965). Kyrgyz-Russian Dictionary. Moscow: Soviet Encyclopedia. 